\title{
Study on Optimum Capacity of Battery Energy Storage System for Wind Power Generator
}

\author{
Tomonobu Senjyu Senior Member (University of the Ryukyus, b985542@tec.u-ryukyu.ac.jp) \\ Yasuaki Kikunaga Student Member (University of the Ryukyus, k078455@eve.u-ryukyu.ac.jp) \\ Atsushi Yona Student Member (University of the Ryukyus, k068470@eve.u-ryukyu.ac.jp) \\ Toshihisa Funabashi Member (Meidensha Corporation, funabashi-t@mb.meidensha.co.jp)
}

Keywords: wind power generator, battery energy storage system, generating power leveling, battery capital cost

In recent years, wind power generator is going to be installed in power systems. However, this power output has fluctuations due to variations in wind speed. An energy storage system is built with the wind power generators since these fluctuations are large. However, if a large energy storage system is installed in the power system, the capital cost will increase. Hence, the smallest optimal size of energy storage system should be determined to save the capital cost.

This paper evaluates the effect of output power leveling by introducing battery, and optimal size of battery for minimum capital cost with an optimization technique. In addition, the optimum control parameters of battery system is determined simultaneously. Hence, the optimal battery size and controller parameters can be determined.

In order to calculate the power output of the wind power generator, we have observed wind speed by weather indicator. Figure 1 shows the wind speed at center point height of wind turbine given by observed wind speed data. Generated power output of a wind generator is calculated by wind speed. Figure 2 shows the wind power

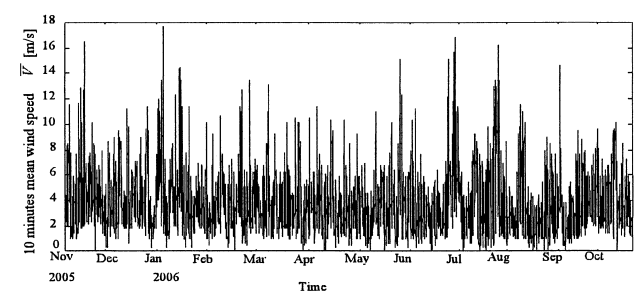

Fig. 1. Wind speed for a year

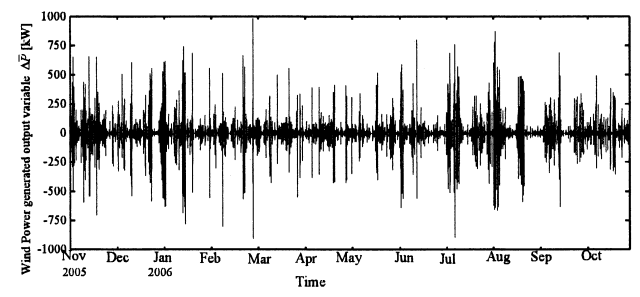

Fig. 2. Generated output variation for a year generator output variable obtained by the backward difference of power output of the wind power generator.

Configuration of wind generator with battery system is shown in Fig. 3. The wind power generator incurs generated output power fluctuations. The battery system smoothes these fluctuations by the action of battery charge/discharge, thereby ensuring the system output is leveled.

By using a battery system introduced into the wind power generator, the power output deviation is evaluated standard deviation and maximum output variable. The demanded output leveling is satisfied with the optimization problem that determines optimum battery system capacity to minimum capital cost. Figure 4 shows the sytem output fluctuations for the optimum values as generated by the optimization process.

As shown in Fig. 4, the output variation of wind power generator with battery system is decreased than that of Fig. 2 .

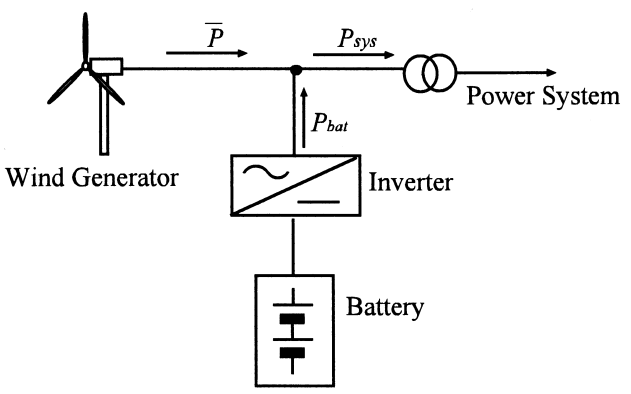

Fig. 3. Configuration of wind power generator with battery system

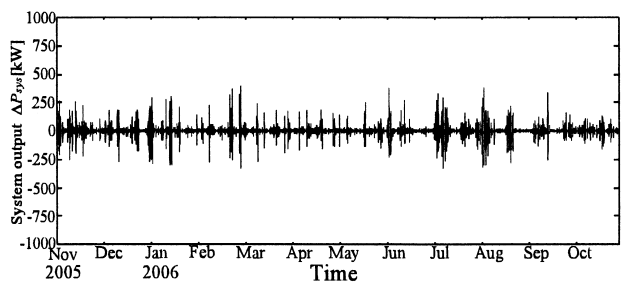

Fig. 4. Power output with optimized battery capacity 


\title{
風力発電機に用いる最適蓄電池設備容量に関する検討
}

\author{
上級会員 千住 智信* 学生員 菊永 康朗* \\ 学生員 與那 篤史* 正員 舟橋 俊久**
}

\section{Study on Optimum Capacity of Battery Energy Storage System for Wind Power Generator}

Tomonobu Senjyu*, Senior Member, Yasuaki Kikunaga*, Student Member, Atsushi Yona*, Student Member, Toshihisa Funabashi**, Member

Generally, the battery is built with wind power generator to level the output power fluctuation of wind power generator, since output power fluctuation of wind power generator is large. However, if large battery is installed in power system, the capital cost for wind power system will increase. Hence, the smallest size of battery should be determined to save the capital cost.

This paper evaluates the effect of the output power leveling by introducing battery, and optimal size of battery is determined. A generated power output of a wind generator is easily calculated by real wind speed data only. However, battery charge/discharge actions are changed by control parameters for battery, it is difficult to decided the optimum battery system capacity. In this paper, output power fluctuation of wind power generator with battery system is calculated and estimated, so that the power output deviation is less than specific value, then minimum capital cost is decided by optimum battery capacity. The proposed technique determines the optimum size and control parameters for installed battery.

キーワード : 風力発電, 蓄電池設備, 発電電力平準化, 蓄電池設備コスト

Keywords: wind power generator, battery energy storage system, generating power leveling, battery capital cost

\section{1. まえがき}

近年，エネルギー資源である石油・石炭などの化石燃料の 枯渇が懸念されている。また，電力需要の増大による $\mathrm{CO}_{2}$ 排出量の増加や，森林破壊による $\mathrm{CO}_{2}$ 吸収源の減少などに より大気中の $\mathrm{CO}_{2}$ 濃度が増加し, 地球温暖化が進行してい る。このような背景から，風力エネルギーを用いた風力発 電システムが欧米を中心に世界各国で注目を集めている。 風力発電システムは無尽蔵な自然エネルギーを活用してお り，また， $\mathrm{CO}_{2}$ を排出しないクリーンな発電設備であるた め, 日本における風力発電総設備容量は今後も増加すると 考えられる(1)。

しかし, 風力発電機の出力電力は風速の 3 乗に比例し, 風速は不規則に変動する。風力発電システムの系統への導

\footnotetext{
* 琉球大学

干 903-0213 沖縄県中頭郡西原町字千原 1 番地

University of the Ryukyus

1, Senbaru, Nishihara-cho, Nakagami, Okinawa 903-0213

** (株) 明電舎

干 103-8515 東京都中央区日本橋箱崎町 36-2

Meidensha Corporation

36-2, Nihonbashi-Hakozakicho, Chuo-ku, Tokyo 103-8513
}

入容量増大に伴い, 風力発電機の発電電力変動によって系 統電圧変動や系統周波数変動が生じることになる(2)。この ため, 電力系統に風力発電機を導入する場合, 発電電力変 動を許容範囲まで平準化しなければならない。特に，大規 模風力発電システムを電力系統に導入する場合の対策が必 要となる。その対策法の一例として, 風力発電機に蓄電池 を併設することが挙げられる。蓄電池を風力発電システム に併設することによって風力発電の発電電力変動を平準化 し, 系統へ与える影響を小さくでき, 風力発電システムの短 周期から長周期までの発電電力変動が補償できる ${ }^{(3) \sim(5) 。 し ~}$ かし, 蓄電池を併設することは設備コストを増加させ, 蓄 電池の特性は劣化するため維持費も必要になる。また, 蓄 電池の設備コスト, 維持費は蓄電池の充放電動作によって 大きな影響を受け，この充放電動作は蓄電池の制御器パラ メータによって決定される。風力発電機に併設された蓄電 池は要求される発電電力変動の平準化を達成することを目 的としている。設備コストの観点から考えると小容量の蓄 電池の導入が望まれるので, 最適蓄電池容量を決定する必 要がある。しかし，これまでの論文では，蓄電池の充放電 による平準化効果は評価しているが, 蓄電池の制御器パラ メータや蓄電池コストまでは十分に検討されていない。 
そこで本論文では, 風力発電機に併設される蓄電池モデ ルを用いて, 発電電力変動を蓄電池の充放電により事業者 の許容する変動まで平準化し, 設備コストが最小となる最 適容量を算出する。用いる蓄電池モデルは 3 つの制御器パ ラメータが存在し, このパラメータの設定によって充放電 結果が左右され, 蓄電池設備容量が変化する。そのため, 提 案する最適容量の算出には, 蓄電池の制御器パラメータを 総当たり的に探索し, さらに蓄電池の設備コストが最小と なるような蓄電池容量, インバー夕容量を局所的に探索す る。また, 提案手法は蓄電池の制御器パラメータの最適化 も同時に達成できる。算出した蓄電池の制御器パラメータ 及び最適容量を適用して, 風力発電機の発電電力変動が要 求される許容範囲まで平準化されたことを合成出力電力変 動より確認した。また, 要求される発電電力変動の条件を 変化させた場合のインバータ容量, 蓄電池容量の最適化を 実行し, 風力発電機に併設する蓄電池設備容量や制御器パ ラメータを検討した。

本論文の構成として，2 章では風力発電機の発電電力を 風速から算出した。3 章では蓄電池モデルを構成し, 蓄電 池設備容量による平準化効果を示した。 4 章では蓄電池シ ステムの最適容量の算定手法を示す。 5 章では蓄電池シス テムの最適容量をシミュレーションより決定し, 提案手法 の有効性を確認した。

\section{2. 風力発電機の発電電力}

風力発電機に併設される蓄電池の充放電を確認するため, 風力発電機の発電電電力データが必要になる。風力発電機 の発電電力算出には風速の実データを用いた。風速の測定 は琉球大学工学部 2 号館の屋上で行った。ただし, 測定期 間は 2005 年 11 月から 2006 年 10 月までの 10 分間平均風 速デー夕を用い，データ損失時と点検時のデータは除いた。 電力系統への風力発電機導入による影響を評価するには, 10 分值データは大きな数值であるが，短時間の実データを 用いるためにはデー夕量の増大や，測定設備費用などの制 約があるので，今回は 10 分間の平均值データを用いてい る。風速のデータより定格出力 $1 \mathrm{MW}$ の風力発電機の発電 電力を計算した。本論文で採用した風力発電機の運転特性 を図 1 に示す ${ }^{(6)}$ 。

$\langle\mathbf{2} \cdot \mathbf{1}\rangle$ 風速の補整と分布風速の実データから発電 電力を算出するには, 風力発電機モデルの地上高と観測点 の地上高が異なるため, 補正を行う必要がある。風速の補 正は，(1) 式を用いた。

$$
V_{z}=V_{h}\left(\frac{z}{h}\right)^{1 / N}
$$

ここで $V_{z}$ : ハブ高さの風速, $V_{h}$ : 観測地点の風速, $z$ : ハブ 高さ, $h$ : 観測地点高さ, $N$ : 補正係数である。

地上の粗度を表す補正係数 $N$ を表 1 に示す (7)。本論文に おいて, 観測地点の地表状態を示す補正係数 $N$ は, 表 1 より 2 とした。なお, 気象観測機を設置した地上高は $21.2 \mathrm{~m}$, 今 回検討の対象とした風力発電機のハブ高さは $60 \mathrm{~m}$ である。

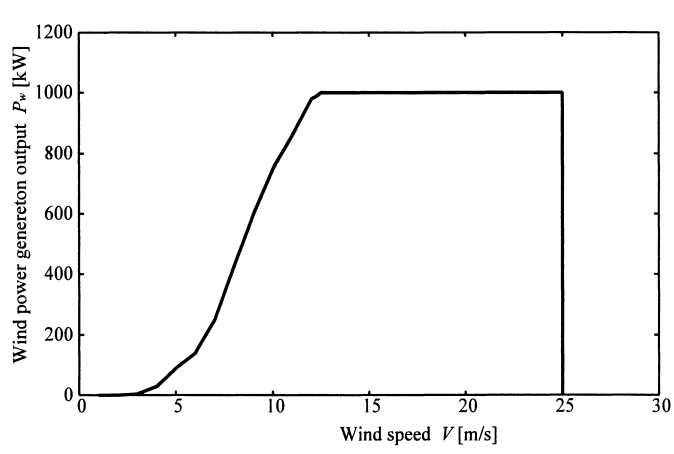

図 1 風力発電機の運転特性

Fig. 1. Output power curve of wind power generator.

表 1 地表状態によるべき級数 $N$

Table 1. Correction value $N$ for ground situation.

\begin{tabular}{ll}
\hline 地表状態 & $N$ \\
\hline \hline 静かな海面など & 10 \\
\hline 平野・草原 & 7 \\
\hline 森林・高い建物のない市街地 & 4 \\
\hline 大都市の郊外周辺 & 3 \\
\hline 大都市の中心付近 & 2 \\
\hline
\end{tabular}

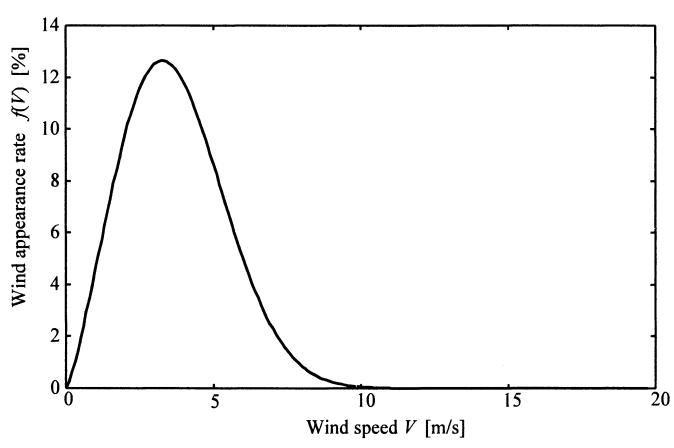

図 2 風速のワイブル分布

Fig. 2. Weibull distribution of wind speed.

本論文では，補正した風速および風速変動值の分布を確 率的に評価する。風速変動值は 10 分間平均風速デー夕の 差分を評価している。風速デー夕の評価は一般に用いられ るワイブル分布を用い, 風速変動值は正規分布により表し た ${ }^{(7)}$ 。ワイブル分布関数 $f$, 分散值 $\sigma_{x}^{2}$, 確率密度関数 $g_{x}$ を (2)～(4) 式に示す。

$$
\begin{aligned}
& f(x)=\frac{k}{c}\left(\frac{x}{c}\right)^{k-1} \exp \left[-\left(\frac{x}{c}\right)^{k}\right] \ldots \ldots \\
& \sigma_{x}^{2}=\frac{1}{i-1} \sum_{j=1}^{i}\left(x_{i}-\mu\right)^{2} \ldots \ldots \ldots \\
& g_{x}(X)=\frac{1}{\sigma_{x} \sqrt{2 \pi}} \exp \left[-\frac{1}{2}\left(\frac{x}{\sigma_{x}}\right)^{2}\right] \ldots
\end{aligned}
$$

ここで $c$ : 尺度定数, $k$ : 形状定数, $\sigma_{x}$ : 標準偏差, $\mu$ : 平 均值である。また, 形状定数 $k$ と尺度定数 $c$ は『NEDO 局 所的風況予測モデル LAWEPS』より $k=2.4$ と設定し ${ }^{(8)}$, $c$ は風速データより (2) 式の対数を計算して $c=4.19$ とし 
た。計算したワイブル分布，正規分布をそれぞれ図 2 , 図 3 に示す。

〈2・2 風力発電機の発電電力 補正した風速データ から風力発電機の発電電力を算出する。換算式として (5) 式を用いた。

$$
P_{w}=\frac{1}{2} \rho A V^{3} \eta
$$

ここで $\rho$ : 空気密度, $A$ : 受風面積, $V$ : 風速, $\eta:$ 発電効率 である。風力発電機の受風面積 $A$ は $2,980 \mathrm{~m}^{2}$, 発電効率 $\eta$ は機械的損失等を考慮して $40 \%$ とした。また，単位面積当 たりの空気密度 $\rho$ は日本の平地の年平均值 $1.225 \mathrm{~kg} / \mathrm{m}^{3}$ と した。一年間の風速と発電電力変動を図 4 , 図 5 にそれぞ れ示す。発電電力変動は 10 分間平均風速データから得ら れた発電電力データの差分から計算した。また，観測日数 は357 日，一年間の平均風速は $3.58 \mathrm{~m} / \mathrm{s}$, 発電電力変動の 標準偏差は $63.4 \mathrm{~kW}$, 最大発電電力変動幅は $981.2 \mathrm{~kW}$ であ る。発電電力変動が正規分布に従うとすると, $\pm 100 \mathrm{~kW}$ の

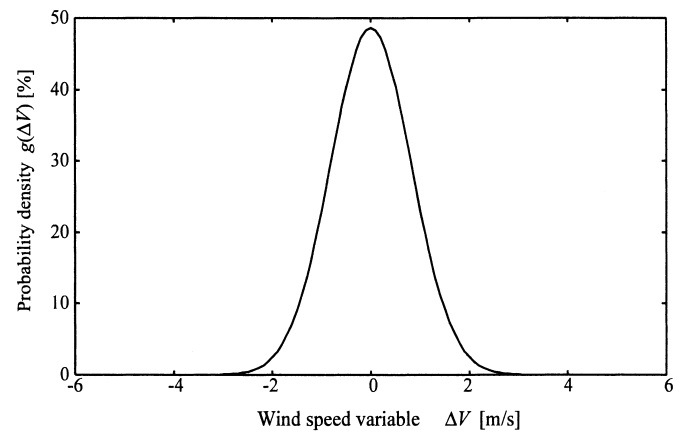

図 3 風速変動の正規分布

Fig. 3. Normal distribution of wind deviation.

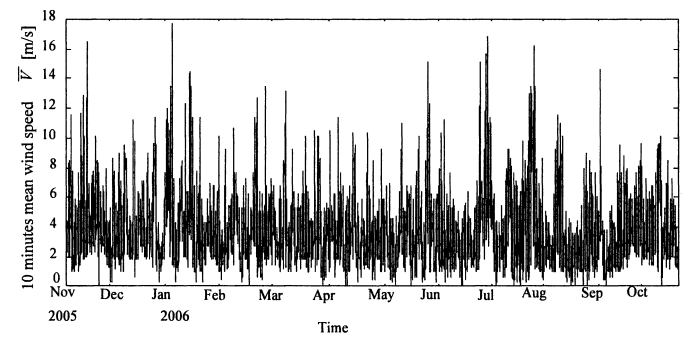

困 4 一年間の風速

Fig. 4. Wind speed for a year.

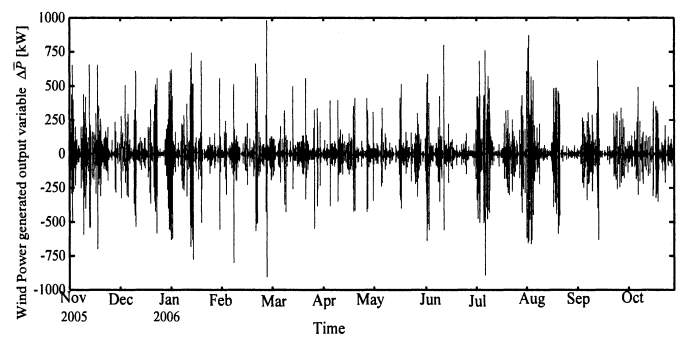

図 5 一年間の発電電力変動

Fig. 5. Generated output variation for a year.
変動範囲に $88.53 \%$ の変動データが含まれることになる。

\section{3. 蓄電池による発電電力変動の平準化}

本章では，風力発電機にインバー夕，蓄電池が併設され ているシステムを考える(図6 参照)。図6のシステムにお いて発電電力の平準化効果は蓄電池容量 ( $\mathrm{kWh}$ 定格容量), インバー夕容量 ( $\mathrm{kW}$ 定格容量) によって大きく異なること を示す。ここで, 風力発電機の発電電力は前章の風速デー タから算出した。また, 今回は風速の 10 分間平均風速デー 夕を用いているため, 蓄電池損失や蓄電池充放電特性によ る一次遅れ特性, 発電電力測定のための一次遅れ特性は短 時間特性として考慮していない。

$\langle\mathbf{3} \cdot \mathbf{1}\rangle$ 電池モデルの構成風力発電機の発電電力変 動を平準化するための電力指令值として発電電力の移動平 均值を用いる。これは風力発電機の過去の発電電力平均值 から算出する。(6) 式は時間 $t$ から過去 $n-1$ までの発電電 力平均值から得られる電力指令值 $P_{\text {com }}$ である。

$$
P_{\text {com }}=\frac{P_{t}+P_{t-1}+P_{t-2}+\cdots+P_{t-(n-1)}}{n} \cdots \cdots \cdots
$$

$n$ を大きくすると平準化効果が大きくなるが, 蓄電池充電 率の変動は大きい。逆に, $n$ を小さくすると蓄電池充電率 の変動は小さいが平準化効果は小さくなる。

図 7 に蓄電池モデルを示す。蓄電池モデルでは風力発電 機からの発電電力 $\bar{P}$ と蓄電池の電力指令值 $P_{c o m}$ の差分 $R$ を算出する。また, 図 7 のモデルでは, 蓄電池の特性劣化 を出来る限り防ぐために, 蓄電池の充放電回数を減らす不

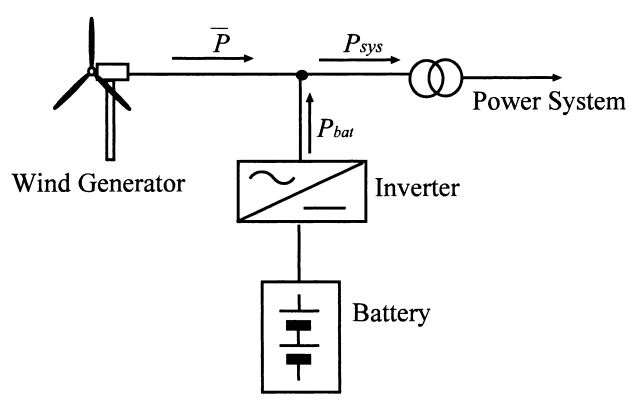

図 6 蓄電池を併設した風力発電設備

Fig. 6. Configuration of wind power generator with battery system.

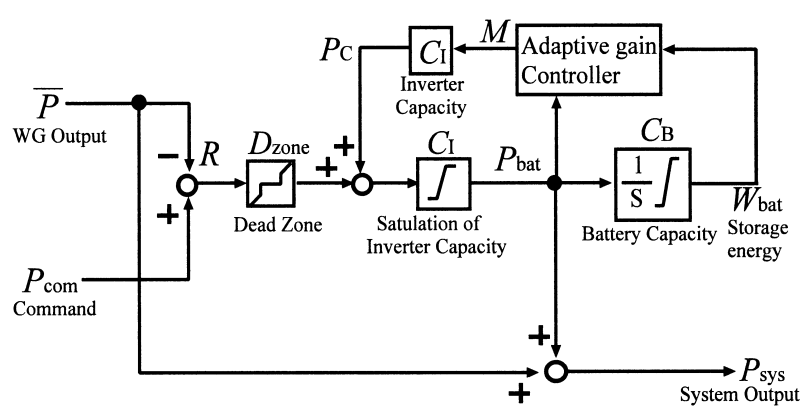

図 7 蓄電池モデル

Fig. 7. Battery system model. 


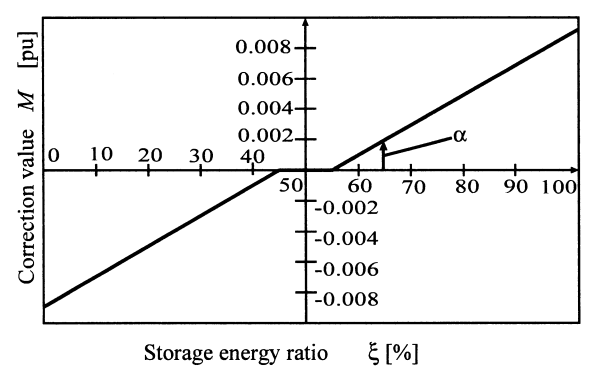

図 8 修正量

Fig. 8. Correction value.

感帯 $D_{\text {zone }}$ を設けている。この不感带は, 風力発電機の発電 電力と電力指令值の差分 $R$ が $\pm D_{z o n e}$ 以上になると動作す る。従って, 大きな変動のみを平準化するように $D_{\text {zone }}$ を 設定することで，充放電回数を抑制できるが， $\pm D_{\text {zone }}$ 以下 の変動が合成出力となるため，系統へ外乱を加えることに なる。しかし， $D_{\text {zone }}$ を小さく設定することにより系統への 外乱を抑制することが可能である。次に， $D_{z o n e}$ の出力にお いて, 修正電力 $P_{C}$ を加算し, これをインバー夕容量 $C_{I}$ を 考慮した充放電のリミッ夕を通すことで蓄電池の出力電力 $P_{b a t}$ としている。 $P_{b a t}$ は正となれば放電動作，負となれば 充電動作となる。また, 蓄電池残存容量 $W_{b a t}$ の推移は $P_{b a t}$ の積分により計算される。このとき，積分器には蓄電池容 量 $C_{B}$ を考慮したリミッ夕を設定している。蓄電池と風力 発電機の合成出力 $P_{s y s}$ は $\bar{P}$ と $P_{b a t}$ を加算することで求ま る。また，蓄電池充電率 $\xi\left(=W_{b a t} / C_{B} 100[\%]\right)$ を $50 \%$ に維持 することを目的として $P_{b a t}$ を蓄電池の残存容量によって変 化させる適応ゲイン制御器を設定した。適応ゲイン制御器 は蓄電池残存容量 $W_{b a t}$ を入力としており, 出力は図 8 に 示すように $\xi$ に応じて修正量 $M$ を出力する。 $M$ と $C_{I}$ の積 が修正電力 $P_{C}$ となる。 $M$ はインバー夕容量 $C_{I}$ を基準値 として採用して扔り， $C_{I}$ の pu 值を出力し, 充電率 $\xi$ の推 移によって修正量 $M$ を変化させる。(7) 式は適応ゲイン制 御器の動作を示しており，Mは傾き $\alpha$ の設定によって変化 する。

$$
M= \begin{cases}\alpha(\xi-55) & \text { if } \xi>55 \text { and } P_{b a t}>0 \\ 0 & \text { if } 55 \geq \xi \geq 45 \\ \alpha(\xi-45) & \text { if } \xi<45 \text { and } P_{b a t}<0\end{cases}
$$

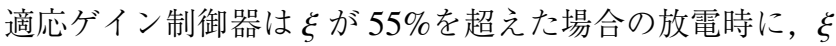
に応じた $M$ を出力する。これにより $\xi$ を $50 \%$ 付近に収束 させている。同様に，45\%より低下した場合の充電時に $M$ を出力する。適応ゲイン制御器の設置により電池残存容量 が増加すると放電量が増加し，蓄電池残存容量が減少する と充電量が増えるようになり， $\xi$ を $50 \%$ 付近で維持させる 動作が可能となる。しかし，傾き $\alpha$ の設定值を大きくする と, 蓄電池の出力電力変動が大きくなり, 発電電力変動の 平準化に悪影響を与える。

$\langle\mathbf{3} \cdot \mathbf{2}\rangle$ 蓄電池設備容量による平準化効果 発電電力の

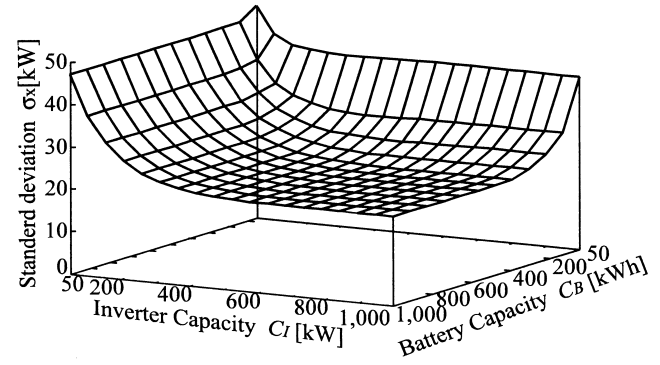

(a) Standard davetation of system output $\left(\sigma_{x}\right)$.

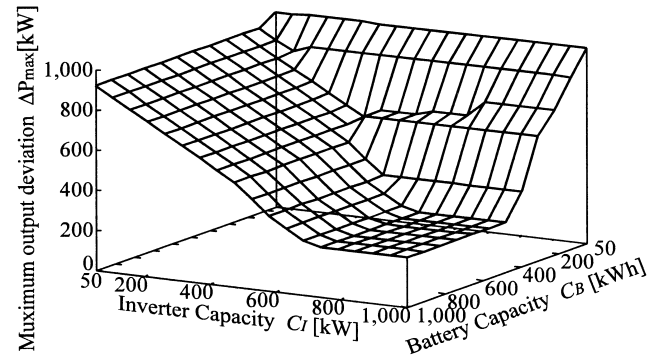

(b) Muximum generated output fluctuation $\left(\Delta P_{\max }\right)$.

図 9 容量による平準化効果

Fig. 9. Effect of leveling by capacity.

平準化効果が蓄電池容量, インバー夕容量の設定により変化 することをシミュレーションより示す。平準化の評価指標 として最大発電電力変動 $\Delta P_{\max }$ と合成出力電力変動 $\Delta P_{s y s}$ の標準偏差 $\sigma_{x}$ を用いる。 $\Delta P_{\max }$ は変動周期 $T$ 内での最大 出力と最小出力の差分から得られる。 $\sigma_{x}$ は合成出力デー夕 間の差分から算出した合成出力電力変動に (3) 式を適用し て算出される。蓄電池による 1 年間における平準化効果を 計算する手順は以下の通りである。

[Step 1] 蓄電池パラメータの $n, \alpha, D_{z o n e}$ を設定する。

[Step 2] 蓄電池容量を設定する。

[Step 3] インバー夕容量を設定する。

[Step 4] 設定された容量で 1 年間の充放電を行う。ま た， $\Delta P_{\max }, \sigma_{x}$ を算出する。

[Step 5] 終了条件を満たすまで繰りかえす。Step 3へ戻 り，インバー夕容量を増加させる。

[Step 6] 終了条件を満たすまで繰りかえす。Step 2へ戻 り，蓄電池容量，を増加させる。

蓄電池容量, インバー夕容量をそれぞれ増加させ, 年間を 通して蓄電池の充放電を行い, 合成出力 $P_{s y s}$ を評価した。な お, パラメータは $n=40 \mathrm{~min}, \alpha=0.0002 \mathrm{pu}, D_{\text {zone }}=0 \mathrm{~kW}$, $T=10 \mathrm{~min}$ とした。また，シミュレーション結果の妥当性 を検討するために, $C_{I}=600 \mathrm{~kW}, C_{B}=500 \mathrm{kWh}$ の容量で 合成出力電力変動 $\Delta P_{s y s}$ を確認した。

$\langle\mathbf{3} \cdot \mathbf{3}\rangle$ 放電シミュレーション 充放電シミュレーショ ン結果を図 9 に示す。蓄電池容量, インバー夕容量を増加 していくことで $\sigma_{x}, \Delta P_{\max }$ は抑制されていることが確認で きる。インバー夕容量を増加させると $\mathrm{kW}$ 容量が増大寸る ので, 指令值に従った平準化が達成できる。蓄電池容量を 増加すると制御結果が良くなるのは，大きな変動が生じた 


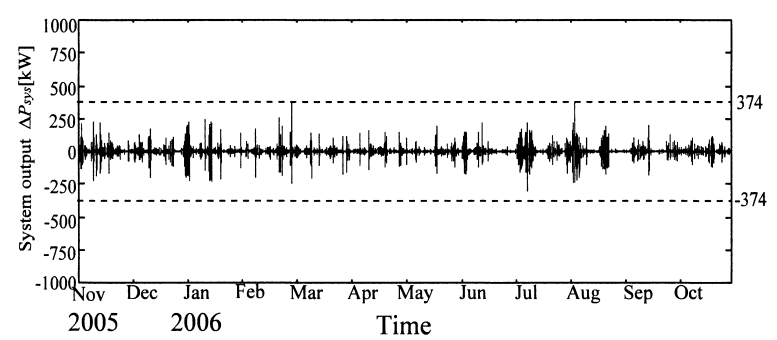

図 10 合成出力変動 $P_{s y s}$

Fig. 10. System output fluctuation $\left(\Delta P_{s y s}\right)$.

時に電力変動分を補償するだけの $\mathrm{kWh}$ 容量があるためであ る。蓄電池容量に関しては, $500 \mathrm{kWh}$ 付近から $\sigma_{x}, \Delta P_{\text {max }}$ が減少しなくなり，これ以上の蓄電池容量増加による平準 化はあまり望めない。そのため, 蓄電池設備容量の検討に は蓄電池の制御器パラメータの最適化が重要になる。また, 設定した蓄電池の制御器パラメータを用いて $C_{I}=600 \mathrm{~kW}$, $C_{B}=500 \mathrm{kWh}$ の条件で得られたシミュレーション結果は, 図 9 に示すように最大発電電力変動 $\Delta P_{\text {max }}=374 \mathrm{~kW}$, 合 成出力変動の標準偏差 $\sigma_{x}=21.43 \mathrm{~kW}$ であった。同条件で 設定した蓄電池を用いて平準化された $\Delta P_{s y s}$ を図 10 に示 す。合成出力電力変動 $\Delta P_{s y s}$ は, 図 5 と比較して蓄電池の 充放電により平準化されており，1 年間を通して $\pm 374 \mathrm{~kW}$ 以下に抑制されていることが確認できる。

\section{4. 蓄電池システムの最適容量算定手法}

風力発電機の発電電力変動を平準化する蓄電池システム は, 蓄電池の制御器パラメータである $n, \alpha, D_{z o n e}$ の設定 により充放電結果が異なる。要求される発電電力変動まで 平準化し, 設備コストが最小になる蓄電池容量, インバー 夕容量を最適化するには, 蓄電池の制御器パラメー夕も最 適值を設定する必要がある。蓄電池の制御器パラメータで ある $n, \alpha, D_{\text {zone }}$, さらに蓄電池容量 $C_{B}$, インバータ容量 $C_{I}$ の最適值を算出するアルゴリズムを構成し, 設備コスト が最小になる解を探索する。

目的関数，制約条件をそれぞれ(8)，(9) 式に示す。蓄電 池システムの設備コストは, (8) 式に示すように蓄電池容量 $C_{B}$, インバーター容量 $C_{I}$ に $\mathrm{kWh}$ 当りの価格 $C_{P}, \mathrm{~kW}$ 当 りの価格 $C_{W}$ の乗算和から得られ, 設備コストが最小とな る解を最適解とする。

目的関数:

$$
\min C_{\text {cap }}=C_{B} C_{P}+C_{I} C_{W}
$$

制約条件：

$$
\left\{\begin{array}{c}
\Delta P d_{\text {max }} \geq \Delta P_{\max } \\
\sigma_{d} \geq \sigma_{x}
\end{array}\right\}
$$

ここで, $C_{P}, C_{W}$ は蓄電池の種類によって設定される。制 約条件は得られた合成出力から評価指標となる $\Delta P_{\text {max }}, \sigma_{x}$ を算出し, 許容される電力変動の最大出力変動幅 $\Delta P d_{\text {max }}$, 標準偏差 $\sigma_{d}$ を越えないように設定した。最適容量ならび

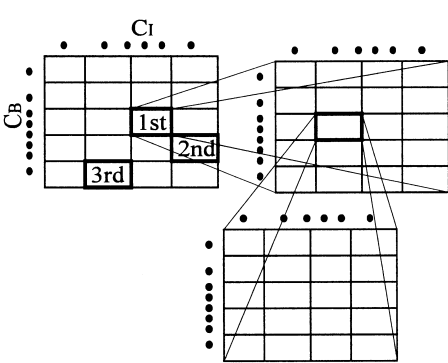

困 11 Step 4 の探索法

Fig. 11. Sarching on Step 4.

に制御器パラメータの決定アルゴリズムは以下のとおりで ある。

[Step 1] 初期設定 許容される発電電力変動の条件と して, 電力変動の最大発電電力変動幅 $\Delta P d_{\text {max }}[\mathrm{kW}]$, 電力変動 の確率的分布 $g\left(P_{d e v}\right)[\%]$ および変動許容範囲 $\pm P_{d e v}[\mathrm{~kW}]$, 変動周期 $T[\mathrm{~min}]$ を設定する。 $g\left(P_{d e v}\right), \pm P_{d e v}$ は合成出力電 力変動 $\Delta P_{s y s}$ を正規分布で表した場合に， $\pm P_{d e v}[\mathrm{~kW}]$ の範 囲に $g\left(P_{d e v}\right)[\%]$ 以上含まれるものとする。

[Step 2] 要求される評価指標の算出 $\Delta P_{s y s}$ の制約条 件となる評価指標には, 最大発電電力変動 $\Delta P d_{\text {max }}$, 標準 偏差 $\sigma_{d}$ を用いる。 $\Delta P d_{\text {max }}$ は初期設定から得られ， $\sigma_{d}$ は $g\left(P_{d e v}\right), \pm P_{d e v}$ から最も近い標準偏差を算出する。 $\Delta P d_{\text {max }}$, $\sigma_{d}$ を制約条件として設定する。

[Step 3] パラメータの設定＼cjkstart蓄電池の充放電は指令值 のサンプル期間 $n[\mathrm{~min}]$, 傾き $\alpha[\mathrm{pu}]$, 不感帯幅 $D_{\text {zone }}[\mathrm{kW}]$ によって結果が変わるため, $n, \alpha, D_{\text {zone }}$ をパラメータとし て設定し, 総当たり的に変化させていく。

[Step 4] 充放電シミュレーション 充放電シミュレー ションを行い, $\Delta P_{s y s}$ から $\Delta P_{\max }, \sigma_{x}$ を評価指標として得 る。(9) 式の制約条件を満たし, 設備コストが最小となる蓄 電池容量, インバータ容量を探索する。

蓄電池容量, インバータ容量の探索では, 先ず大きい幅 で増加させ，次に増加幅を細かくして探索する。これを 2 回繰返し, 図 11 に示すように目的関数に従い局所探索を 行う。また, 局所解への収束を防ぐため, 設備コストが最 小となる上位 3 つの解をそれぞれ細かく探索し，与えられ た蓄電池の制御器パラメータでの最適解を得る。 $C_{I}, C_{B}$ の 探索では, 平準化効果を示した図 9 より局所解の少ない特 性であるため，およびシミュレーション時間短縮のために この手法を採用した。

[Step 5] 評価＼cjkstart充放電シミュレーションより, 設定し た制御器パラメータでの最適解を評価し Step 3 へ戻る。蓄 電池の制御器パラメータは総当たり的に変化させて設定す る。終了回数を満たすと終了する。

5. シミュレーション

〈5・1〉 シミュレーション条件（9）式の制約条件を満 たし設備コスト $C_{c a p}$ が最小となる最適解を示す。使用した 蓄電池は $\mathrm{NaS}$ 電池を想定し, $\mathrm{NaS}$ 電池の $C_{P}, C_{W}$ を以下 
表 2 シミュレーションパラメータ

Table 2. Simulation parameters.

\begin{tabular}{|l||cccc|}
\hline & $\Delta P d_{\max }[\mathrm{kW}]$ & $g_{P_{\text {dev }}}[\%]$ & $\pm P_{\text {dev }}[\mathrm{kW}]$ & $T[\min ]$ \\
\hline case1 & 400 & 99.95 & 100 & 10 \\
\hline case2 & 300 & 99.95 & 100 & 10 \\
\hline case3 & 400 & 99.95 & 70 & 10 \\
\hline case4 & 400 & 99.95 & 100 & 20 \\
\hline
\end{tabular}

表 3 シミュレーション結果

Table 3. Simulation result.

\begin{tabular}{|c|c|c|c|c|}
\hline & case 1 & case 2 & case 3 & case 4 \\
\hline [min] & 30 & 40 & 50 & 60 \\
\hline [pu] & 0.0004 & 0.0002 & 0.0001 & 0.0008 \\
\hline$D_{\text {zone }}[\mathrm{kW}]$ & 10 & 0 & 0 & 0 \\
\hline$\Delta P_{\max }[\mathrm{kW}]$ & 399 & 299 & 399 & 399 \\
\hline$[\mathrm{kW}]$ & 27.48 & 21.47 & 18.76 & 28.60 \\
\hline$[\mathrm{kW}]$ & 582 & 675 & 574 & 587 \\
\hline$C_{B} \quad[\mathrm{kWh}]$ & 231 & 392 & 431 & 634 \\
\hline$C_{c a p}$ & $1,034,700$ & $1,286,900$ & $1,162,700$ & $1,324,300$ \\
\hline
\end{tabular}

に示す ${ }^{(9)}$ 。

$\mathrm{NaS}$ 電池の $\mathrm{kWh}$ あたりの価格 $C_{P}: 700 \$ / \mathrm{kWh}$

$\mathrm{NaS}$ 電池の $\mathrm{kW}$ あたりの価格 $C_{W}: 1,500 \$ / \mathrm{kW}$

なお，本論文では短時間の充放電を目的としているため, 蓄電池の自己放電は考慮しておらず, $C_{P}$ に電力量損失に伴 う損失価格は含んでいない。

許容される発電電力変動の制約条件となるシミュレーショ ンパラメータを表 2 へ示す。この 4 つの case で最適解を 探索するシミュレーションを行った。

〈5・2〉 シミュレーション結果 各 case での最適解と なった蓄電池の制御器パラメータ $n, \alpha, D_{z o n e}$, 合成出力電 力変動の標準偏差 $\sigma_{x}$, 最大発電電力変動 $\Delta P_{\max }$, インバー ター容量 $C_{I}$, 蓄電池容量 $C_{B}$, 設備コスト $C_{c a p}$ を表 3 に 示す。各 case で算出した最適解を用いて, 風力発電機の発 電電力変動を蓄電池併設により平準化した $\Delta P_{s y s}$ を図 12 図 15 に示す。 $\Delta P_{\text {sys }}$ は合成出力の差分から計算した。各 caseのシミュレーションより以下の結果が得られた。

(case 1) サンプル期間 $n$ を増加させると, 設備コスト $C_{c a p}$ が増加した。蓄電池残存容量の変動が大きく満放電, 満充電時の発電電力変動を平準化できないため $\Delta P_{\text {max }}$ が増 大した。また， $n$ が小さい場合でも，不感帯 $D_{z o n e}$ を設定 すると解が得られた。この理由として制約条件が比較的厳 しくない条件であることが挙げられる。図 12 では不感帯 を設定したため, $D_{\text {zone }}$ 内での発電電力変動は平準化されず $\Delta P_{s y s}$ として出力されている。

(case 2) $n \leq 3$ となるように設定すると解が得られなかっ た。 $n$ を小さい值に設定すると, $\Delta P_{\text {max }}$ を $300 \mathrm{~kW}$ 以内に 抑制する制約条件を満たせなかったためである。得られた $C_{c a p}$ を case 1 で得られた值と比較すると, 蓄電池容量は 増加している。しかし, case 1 の合成出力電力変動シミュ レーション結果では $\pm 300 \mathrm{~kW}$ を越えているのは年に数回 しかないため, 設備コストの増加によるメリットは case 1

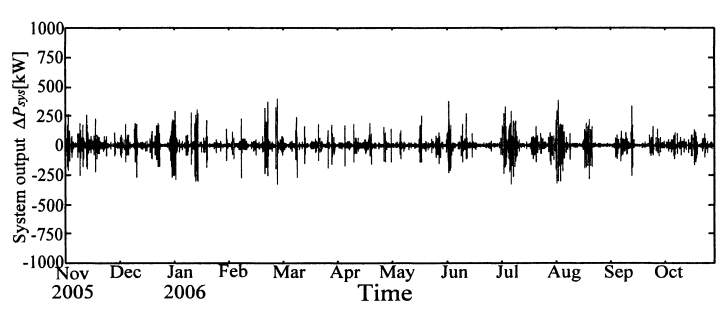

図 12 case 1 の最適解での制御結果

Fig. 12. Power output with optimized battery capacity (case 1).

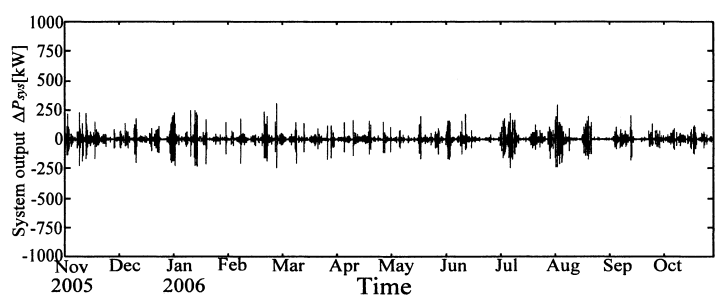

図 13 case 2 の最適解での制御結果

Fig. 13. Power output with optimized battery capacity (case 2).

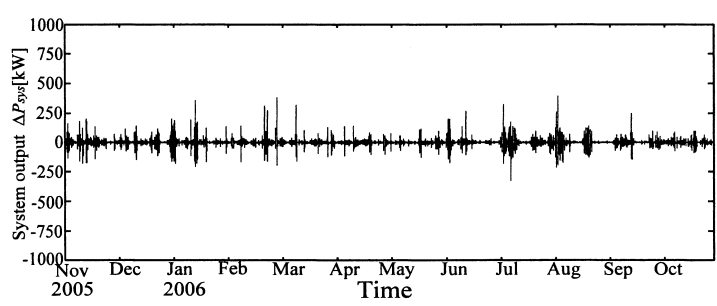

図 14 case 3 の最適解での制御結果

Fig. 14. Power output with optimized battery capacity (case 3).

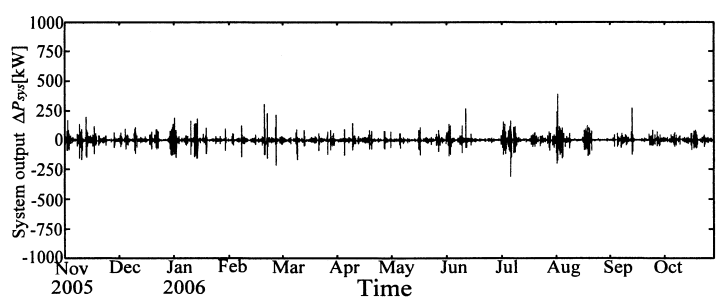

図 15 case 4 の最適解での制御結果

Fig. 15. Power output with optimized battery capacity (case 4).

と比較すると小さいといえる。

(case 3) case 1 の結果と比較すると, 蓄電池容量, 設備 コストが増加した。また， $n$ も 5 以上に設定しなければ解 が得られなくなり, 発電電力变動の確率的な分布を小さく するためには十分な蓄電池容量が必要になる。設備コスト は case 1 より増加したが, 図 14 の $\Delta P_{\text {sys }}$ は充分に平準化 されている。また， $\alpha, D_{\text {zone }}$ は，充分小さい值にしなけれ ば設備コストが増大し，解が得られないこともある。これ らの制御器パラメータは標準偏差に大きな影響を及ぼて 
いる。設備コストを抑制するためには, 風力発電機の発電 電力変動が小さい地域を選ぶことが重要となる。

(case 4) 本ケースは，20 分間の変動を平準化させる制 約条件で最適化している。各 case で最も設備コストが増大 する結果となった。考慮する平準化期間を長く取ると発電 電力変動が大きくなるため, 変動を抑制する蓄電池容量, 設 備コストが増加した。長周期の発電電力変動を抑制するに は大容量の蓄電池設備が必要になるため, 風車のピッチ角 制御や電力系統との協調制御により平準化を行うことが望 ましい。

\section{6. むすび}

本論文では, 風速の実データより定格出力 $1 \mathrm{MW}$ の風力 発電機が出力する発電電力を算出し, 風力発電機に併設さ れる蓄電池モデルを用いて許容された発電電力変動まで平 準化を行い, さらに設備コストが最小となる蓄電池の最適 容量の算出を行った。提案した蓄電池モデルの充放電動作 は蓄電池の制御器パラメータによって大きな影響を受ける ため, 制御器パラメータの最適化も同時に行った。許容さ れる発電電力変動まで平準化することを制約条件とし, 合 成出力電力変動が制約条件を満たすと共に設備コストが最 小となる最適な蓄電池容量, インバータ容量及び蓄電池の 制御器パラメータを決定することができた。

(平成 19 年 3 月 1 日受付, 平成 19 年 7 月 23 日再受付)

\section{文献}

(1) T. Senjyu, R. Sakamoto, N. Urasaki, H. Higa, K. Uezato, and T. Funabashi: "Output Power Control of Wind Turbine Generator by Pitch Angle Control using Minimum Variance Control”, IEEJ Trans. PE, Vol.124, No.12, pp.1455-1462 (2004-12) (in Japanese)

千住智信 ·坂本良成 · 浦崎直光 · 比嘉広樹 ·上里勝実 · 舟橋俊久 : 「最小分散制御を用いた風力発電機のピッチ角制御による出力変動 の抑制」, 電学論 B, 124, 12, pp.1455-1462 (2004-12)

(2) R. Sakamoto, T. Senjyu, T. Kaneko, N. Urasaki, T. Takagi, and S. Sugimoto: "Output Power Leveling of Wind Turbine Generator by Pitch Angle Control Using $H_{\infty}$ Control", IEEJ Trans. PE, Vol.127, No.1, pp.86-94 (2007-1) (in Japanese)

坂本良成 · 千住智信 - 金子敏章 - 浦崎直光 ·高木輝夫 · 杉本重幸 : $\left\lceil H_{\infty}\right.$ 制御を用いた風力発電機のピッチ角制御による出力電力変動抑 制」, 電学論 B, 127, 1, pp.86-94 (2007-1)

(3) T. Murakami, A. Yokoyama, and Y. Tada: "Basic Study on Battery Capacity Evaluation for Load Frequency Control (LFC) in Power System with a Large Penetration of Wind Power Generation", IEEJ Trans. PE, Vol.126, No.2, pp.236-242 (2006-2) (inJapanese)

村上明子・横山明彦・多田泰之：「大容量風力発電が導入された電力 系統における周波数制御のための蓄電池容量評価に関する基礎的検 討」, 電学論 B, 126, 2, pp.236-242 (2006-2)

(4) K. Yoshimoto, T. Nanahara, G. Koshimizu, and K. Kato: "Operational Simulation of Battery Energy Storage System for Smoothing Output Fluctuation of a Wind Farm", Proc. of 2005 Annual Conference, Power \& Energy Society, IEE Japan, No.238 (2005) (in Japanese) 由本勝久 · 七原俊也·典水源太郎・加藤和男 :「ウィンドファームの出 力変動の平滑化を目的とした蓄電池システムの運用シミュレーショ ン」, 平成 17 年電気学会電力・エネルギー部門大会, No.238 (2005)

(5) N. Suzuki, T. Matsushita, N. Kosugi, and T. Hiyama: "The Effect of Smoothing out Fluctuation of Wind Power Generation System with Battery Energy Storage System", Proc. of 2006 Annual Conference, Power \& Energy Society, IEE Japan, No.394 (2006) (in Japanese)
鈴木直人・松下哲也・小杉成史・檜山 隆 :「蓄電池併設風力発電 の出力変動平準化効果について」, 平成 18 年電気学会電力・エネル ギー部門大会, No.394 (2006)

(6) E. Ueda, K. Inoue, M. Sibata, and Y. Hayashi: "Mitsubishi New Wind Turbine, MWT-1000A", Mitsubishi Technical Report, Vol.41, No.1 (2004-1) (in Japanese)

上田悦紀・井上厚助・柴田昌明・林 義之 :「三菱重工の新 $1000 \mathrm{~kW}$ 風車, MWT-1000A」, 三菱重工技報, 41, No.1 (2004)

（7）牛山 泉：風車工学入門一基礎知識から風力発電技術まで一, 森北 出版 (2002)

（8） NEDO 技術開発機構：局所的風況予測モデル LAWEPS, Japan Weather Association (2002-2005)

http://www2.infoc.nedo.go.jp/nedo/top.html

(9) Electricity Storage Association Web site: http://www.electricitystorage.org/

千 住 智 信 (上級会員) 1963 年生。1988 年 3 月琉球大学大

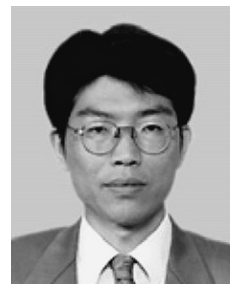
学院工学研究科修士課程電気・情報工学専攻修了。 同年 4 月同大学工学部電気工学科助手, 1994 年 11 月より同大学同学部電気電子工学科助教授, 2001 年 4 月より同大学同学部電気電子工学科教授, 現 在に至る。博士 (工学)。同期機の安定性ならび に制御に関する研究, FACTS 機器の制御, アドバ ンスト制御を導入した電動機とパワーエレクトロ ニクス機器ならびに自然エネルギー開発に従事。電子情報通信学会, 計測自動制御学会, IEEE シニア会員, IET 会員。

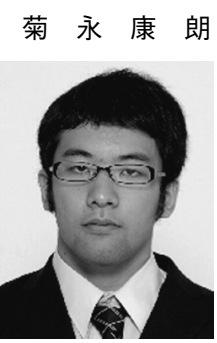

(学生員) 1984 年生。 2007 年 3 月 琉球大学工学 部電気電子工学科卒業。同年 4 月同大学大学院理 工学研究科博士前期課程電気電子工学専攻入学, 現在に至る。主として風力発電機の発電電力変動 平滑化に関する研究に従事。電子情報通信学会学, IEEE 学生会員。

與 那 篤 史 (学生員) 1982 年生。2006 年 3 月 琉球大学工学

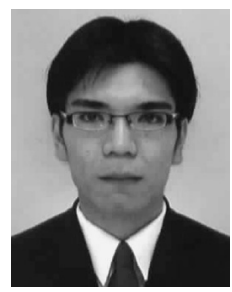
部電気電子工学科卒業。同年 4 月同大学大学院理 工学研究科博士前期課程電気電子工学専攻入学, 現在に至る。主として風力発電設備と太陽光発電 設備の発電電力予測に関する研究に従事。電子情 報通信学会学, IEEE 学生会員。

舟 橋 俊 久 (正員) 1951 年生。1975 年名古屋大学工学部電

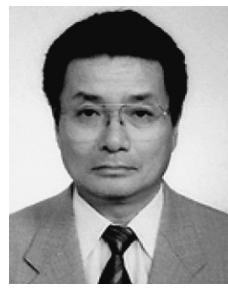
気工学科卒業。同年 4 月 (株) 明電舎入社。現在 に至る。博士 (工学)。英国技術士 (C.Eng)。主 として電力, 系統解析, 分散型電源に関する研究 に従事。IEEE シニア会員。IET 会員。 